\title{
Mitigation of concrete reinforced steel corrosion by penta sodium triphosphate: physicochemical and electrochemical investigations
}

\author{
Binsi M. Paulson ${ }^{1} \cdot$ K. Joby Thomas ${ }^{1} \cdot$ Vinod P. Raphael $^{2} \cdot$ K. S. Shaju ${ }^{2} \cdot$ K. Ragi ${ }^{1}$
}

Received: 29 May 2020 / Accepted: 23 September 2020 / Published online: 12 October 2020

(c) Springer Nature Switzerland AG 2020

\begin{abstract}
The capacity of penta sodium triphosphate (PST) to avert the steel reinforcement corrosion in contaminated concrete by $\mathrm{NaCl}$ was investigated for 480 days using electrochemical impedance spectroscopy, potentiodynamic polarization, half-cell potential and gravimetric methods. The mechanism of interaction of PST molecules and the changes took place on the steel surface assessed using spectroscopic and microscopic analysis. Compression tests of the concrete specimens were performed to monitor the strength of concrete after the addition of PST. Investigations proved that PST acts as a competent admixture for inhibiting the corrosion of steel reinforcement in concrete without affecting its strength for a longtime.
\end{abstract}

Graphic abstract
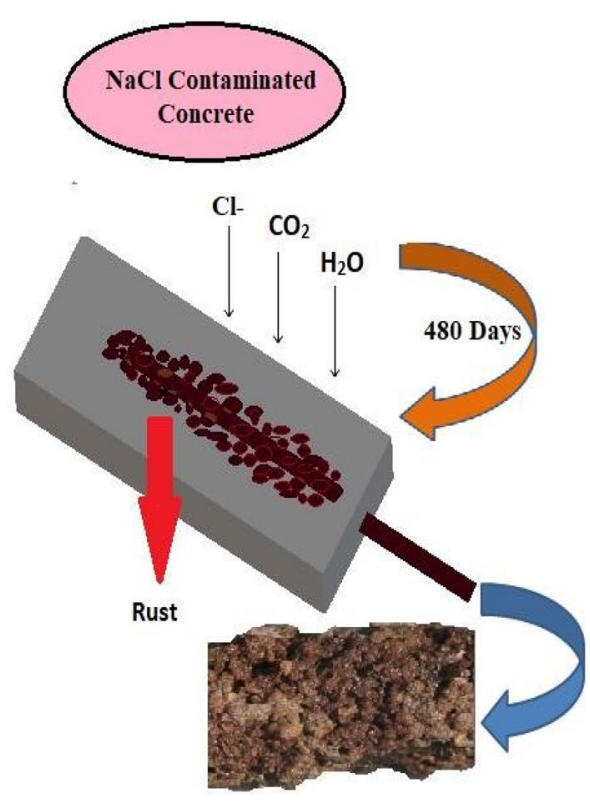
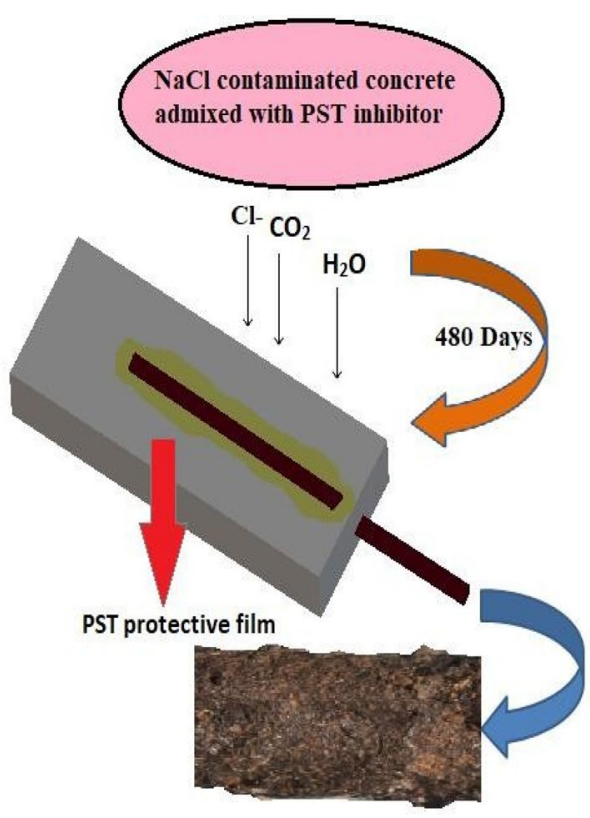

Keywords Corrosion · Inhibitor $\cdot$ Concrete steel reinforcement $\cdot$ Admixture

K. Joby Thomas, drjobythomask@gmail.com; jobythomask@stthomas.ac.in | ${ }^{1}$ Center for Electrochemical Studies, Department of Chemistry, St. Thomas' College (Autonomous), Thrissur, Kerala 680001, India. ${ }^{2}$ Department of Chemistry, Government Engineering College, Thrissur, Kerala 680009, India. 


\section{Introduction}

Steel reinforced concrete is an economically successful material for construction. It can cast to various shapes and designs which is strong and have a long life time. Over the last few years, intense investigations are taking place on the corrosion of reinforced steel in concrete. Corrosion is deleterious to the service life of concrete structures in respect of significant depletion of their durability results in increasing the maintenance expenditure than construction cost. In some cases, a reduction in lifetime occurs due to the disintegration of steel rebar in concrete structures [1-10]. Broadly, the term concrete corrosion indicates chemical or physicochemical disintegration of concrete components and structures, due to the attack of corroding agents like $\mathrm{CO} 2$, chlorides, sulphates, fluorides, nitrates etc. on the reinforcing steel bars [11-16]. Steel rebar in concrete is protected by a passive film formed by the alkalinity of concrete, which can be disrupted by the reaction with above mentioned reactants [17-22]. The corrosion of the rebars drops the structural integrity of the concrete bridges, pipelines, buildings and other assets constructed. When the concentration of chlorides exceeds a threshold value of about $0.4-1 \%$ by weight of cement, corrosion is initiated and pitting corrosion occurs [23-30]. This results the formation of hydrated iron oxide or rust on steel rebar, which slowly expands and generates an internal pressure in concrete leading to the structural deterioration.

Varied strategies were developed by researchers to avert the concrete corrosion which delaying or preventing the process of corrosion. These strategies comprise coatings, use of cathodic protection systems, stainless steel reinforcing bars, and fibre glass. Among numerous available techniques, mixing of corrosion inhibitors (admixture) during the casting of concrete is a simple and cost friendly corrosion prevention method [31-36]. Because of the user friendly nature, inhibitors are extensively employed to lessen the corrosion rate of steel reinforcement in the concrete structures. Generally, the corrosion inhibition efficacy of inhibitors depends upon various factors including their molecular size, way of interaction and complex formation with metals [37-39]. Corrosion inhibitors are mainly categorized as organic corrosion inhibitors and inorganic corrosion inhibitors. According to their mechanism of protection, they again classified as anodic, cathodic and mixed inhibitor. When inhibitor mixed with concrete results to a change of corrosion potential $\left(\mathrm{E}_{\mathrm{corr}}\right)$ towards the negative direction. If the shift of $E_{\text {corr }}$ is $>85$ and concerning $E_{\text {corr }}$ of the uninhibited specimen along with the significant change of cathodic, or anodic slopes, the inhibitor can be viewed as anodic or cathodic. While the change of $E_{\text {corr }}$ values is $<85 \mathrm{mV}$, the inhibitor behaves as mixed type inhibitor [40]. Based on the mode of application, corrosion inhibitors can be categorized as; admixed inhibitors and migrating inhibitors. Admixed inhibitors are mixed with concrete during preparation time. Corrosion inhibitors can significantly increase the life time of concrete and reduce costs of maintenance of steel reinforced concrete structures for a typical time period of $30-40$ years. The function of these inhibitors is to increase the time taken for the disintegration of steel reinforced concrete. Corrosion inhibitors may have some effects on the properties of concrete. The inhibitors may alter (1) the rate of chloride ingress from the surroundings (2) the degree to which chlorides are physically trapped in the concrete structure (3) the amount of chlorides that can tolerate by steel without damage of passive film and (4) the intake of dissolved oxygen. Structures prepared in the 1970s mixed with calcium nitrates show no significant amount of deterioration [41, 42]. Later, several corrosion inhibitors including calcium nitrites, amino acids, saturated and unsaturated fatty acid ester of carboxylic acid etc. are marketed for concrete protection [43]. But these inhibitors are not only toxic, high-cost but also threat to human health. Among the most known inhibitors, a user friendly inhibitor with maximum efficiency is far from being developed. Thus many researchers are interested in the area of concrete corrosion and establishing ecofriendly and cost-effective inhibitors with appreciable efficiency. Palm oil leaf extracts doped with silver nanoparticle [44] and green inhibitors like Welan gum and Neem gum are reported recently [45].

This paper highlights the prolonged corrosion inhibition efficiency of a user friendly inhibitor, penta sodium triphosphate (PST) as an admixture in concrete rectangular prism contaminated with $3.5 \% \mathrm{NaCl}[46,47]$. Penta sodium triphosphate is an inorganic compound with molecular formula $\mathrm{Na}_{5} \mathrm{P}_{3} \mathrm{O}_{10}$. It is a colourless salt, which occurs both in anhydrous and hexahydrate form. It has a molar mass of $367.864 \mathrm{~g} / \mathrm{mol}$ and $2.52 \mathrm{~g} / \mathrm{cm}^{3}$ density. It is highly soluble in water and the melting point is $622^{\circ} \mathrm{C}$. It can bind with metals as a bidentate as well as a tridentate chelating agent.

Metallic corrosion is considered as the gradual deterioration of metals by an electrochemical phenomenon with their environment. Thus electrochemical methods can be used for determining corrosion rate with certainty [48-53]. The fast development of the computer technology and fundamental electrochemistry leads to fabrication of perfect potentiostats acceptable for the investigation of the rate of corrosion which help the researchers to introduce rate controlling mechanisms [54-59]. The present investigation is the continuous monitoring of corrosion inhibition 
efficiency of penta sodium triphosphate by measuring the corrosion rate of reinforced steel rebar electrochemically and gravimetrically. For simulating the real condition, concrete rectangular prisms with steel reinforcement were fabricated. Corrosion monitoring studies such as measurements of half-cell potentials, electrochemical impedance spectroscopy (EIS), potentiodynamic polarization studies and gravimetric analysis were conducted. Surface morphological and IR spectroscopic analysis were carried to describe the mechanism of the inhibition by PST. To assess the influence of PST on concrete strength, compressive strength measurements were done.

\section{Experimental procedure}

\subsection{Preparation method for concrete specimens}

Concrete rectangular prisms of dimension $100 \times 60 \times 60 \mathrm{~mm}$ were prepared by inserting a steel bar of length $150 \mathrm{~mm}$, diameter $1 \mathrm{~cm}$ and surface area $10 \mathrm{~cm}^{2}$. The concrete rectangular prisms were prepared by using ordinary Portland cement, gravel, sand and water ( $\mathrm{w} / \mathrm{c}$ ratio 0.5 ). The steel rebars having an approximate composition P: 0.1\%, Mn: 0.62\%, S: 0.021\%, S: 0.04\% and rest Fe (estimated by EDAX method) and made rust free by immersing for $10 \min$ in $2 \mathrm{M} \mathrm{HCl}$, washed, dried, weighed and embedded in the concrete specimen while casting. The concrete specimens were taken from the moulds after $24 \mathrm{~h}$ and were exposed to wet (Fig. 1). After the curing period, we coated epoxy resin on the five sides of the concrete specimen and placed an open reservoir $(50 \times 20 \times 20 \mathrm{~mm})$ on the sixth side with silicon adhesive and polypropylene sheet. $20 \mathrm{ml}$ of $3.5 \% \mathrm{NaCl}$ was allowed to remain in the open reservoir for one month to initiate the corrosion process. Two sets

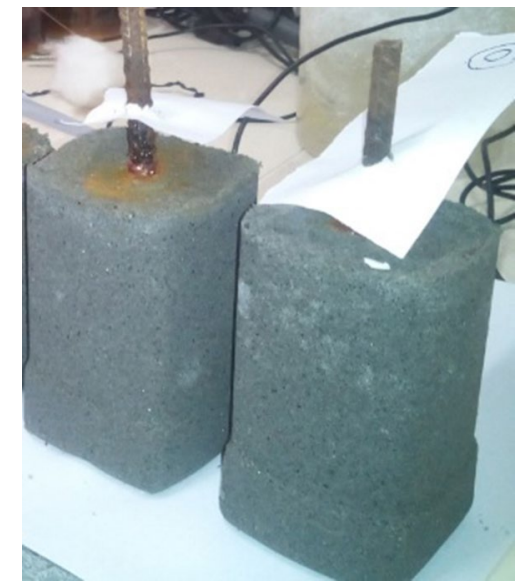

Fig. 1 Concrete rectangular prism of concrete specimens were casted with and without the addition ofPST.

SAMPLE 1: Prepared with a nominal mix ratio of 1:1.5:3 (cement, sand and gravel) and contaminated with $3.5 \% \mathrm{NaCl}$.

SAMPLE 2: Prepared with a nominal mix ratio of 1:1.5:3 (cement, sand and gravel), added PST as $2.5 \%$ of weight of cement and contaminated with $3.5 \% \mathrm{NaCl}$.

To find out the optimum amount of PST in concrete, half-cell potential analysis of steel rebar (against Saturated Calomel Electrode) immersed in concrete pore solution containing various concentrations of PST and $3.5 \% \mathrm{NaCl}$ was done. Lowest value of half-cell potential (magnitude) was observed for the steel rebar immersed in concrete pore solution containing PST at concentration of $2.5 \%$ of weight of cement. After this examination, we fixed optimum amount of PST as $2.5 \%$ of weight of cement.

\section{Corrosion monitoring techniques}

\subsection{Electrochemical investigations}

\subsubsection{Potentiodynamic polarizationstudies}

Electrochemical studies were conducted using Iviumcompactstat-e workstation, and the corrosion rate was evaluated by potentiodynamic polarization method. Three electrode cell system contains saturated calomel electrode (SCE) as reference electrode, steel rebar embedded in the concrete specimen as working electrode and stainless-steel mesh covered on concrete specimen as counter electrode were used for the potentiodynamic polarization studies. A wet sponge inserted between SCE and concrete surface maintained the electrical contact. Prior to each measurement, the concrete prisms were immersed in water for half an hour and maintain open-circuit (OC) as stable. Potentiodynamic studies were conducted at 160, 320 and 480 days. Parameters like exposed steel area $\left(10 \mathrm{~cm}^{2}\right)$, equivalent weight of steel $(27.92 \mathrm{~g})$ and density of steel $(7.88 \mathrm{~g} / \mathrm{mL})$ were used to calculate the corrosion current density and inhibition efficiency. Polarization analysis was performed in the potential range +250 to $-250 \mathrm{mV}$ against corrosion potential at a scan rate of $1 \mathrm{mV} / \mathrm{s}$ [60]. The schematic diagram of the experimental set up for electrochemical studies is represented in Fig. 2.

The corrosion inhibition efficiency of PST was calculated using equation: 


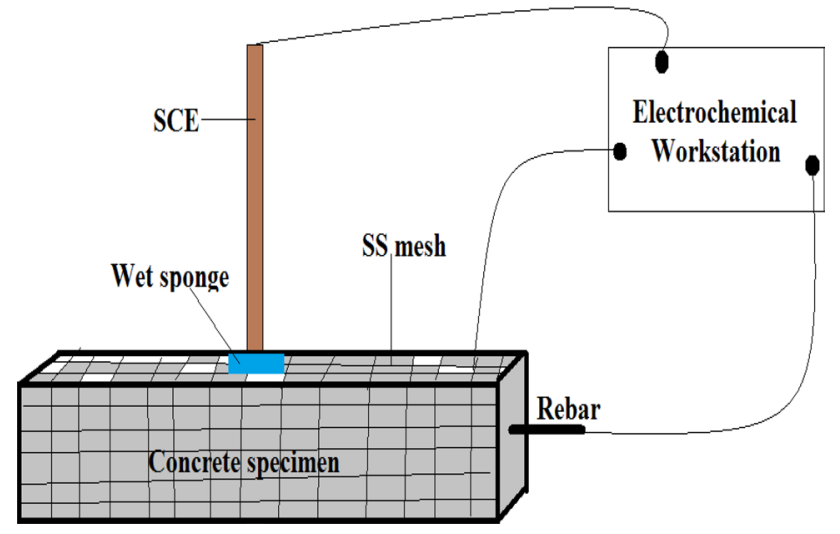

Fig. 2 Three electrode system for electrochemical studies

$\eta_{\mathrm{pol}} \%=\frac{i_{\text {corr }}-l i_{\text {corr }}^{\prime}}{l i_{\text {corr }}} \times 100$

where $i_{\text {corr }}$ and $i_{\text {corr }}$ are corrosion current densities of steel reinforcement in sample 1 and sample 2 respectively.

\subsubsection{Electrochemical impedance spectroscopic studies} (EIS)

Electrochemical impedance spectroscopy (EIS)was also used to analyse the electrochemical behaviour of the corroding system. Ivium compactstat-e workstation with conventional three-electrode system (as described in polarization studies) was used for the EIS test. EIS studies were conducted at constant potential with the frequency range $1 \mathrm{kHz}-100 \mathrm{mHz}$, employing $10 \mathrm{mV}$ amplitude as excitation signal [61]. The charge transfer resistance $\left(R_{c t}\right)$ obtained by the analysis of Nyquist curves used to determine the corrosion inhibition efficacy of PST as described in Eq. 2.

$\eta_{\mathrm{EIS}} \%=\frac{R_{c t}^{\prime}-R_{c t}}{R_{c t}} \times 100$

where $R_{\mathrm{ct}}$ and $R_{\mathrm{ct}}^{\prime}$ are the charge transfer resistances of working electrode, in sample 1 and sample 2 respectively.

\subsubsection{Half-cell potential measurements}

Half-cell potential measurement is the most approved technique for monitoring immediate corrosion response of steel reinforced concrete specimens. For this, a high impedance voltmeter (HP E2378A) was connected to a reference electrode $(\mathrm{SCE})$ and steel rebar portion protruded from the concrete specimen.In this created cell system, SCE acted as cathode and steel rebar acted as anode. Figure 3 represents the schematic diagram of the cell. The working electrode potential was calculated by subtracting

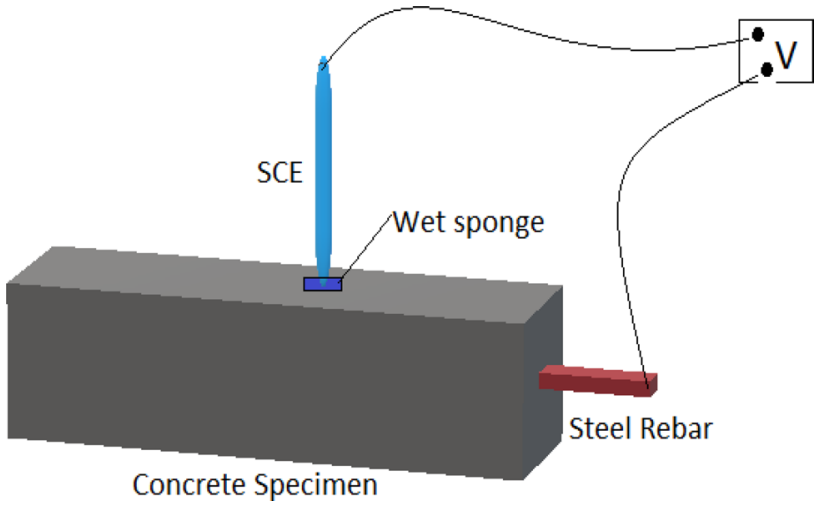

Fig. 3 Electrode system for half-cell potential measurement

cell EMF from the SCE potential. Sixteen readings were taken during 480 days ( 1 reading per month).

\subsection{Gravimetric studies}

During the preparation of concrete specimens, steel rebars having same surface area were made rust free by immersing in $2 \mathrm{M} \mathrm{HCl}$ for $5 \mathrm{~min}$, washed, dried, and the weight was noted. Concrete samples were smashed, and the steel reinforcements were taken after 480 days of investigation, the adhered rust was removed by pickling with $2 \mathrm{M} \mathrm{HCl}$ for $10 \mathrm{~min}$, washed, dried and weighed. The approximate corrosion inhibition efficiency of PST on the steel reinforcement was calculated by Eq. 3 .

$\eta \%=\frac{w_{0}-w}{w_{0}} \times 100$

where $w_{0}$ and $w$ are the weight loss of steel rebars of sample 1 and sample 2 respectively.

\subsection{Spectroscopic and microscopicstudies}

To elucidate the interaction mechanism of PST on reinforced steel rebar in concrete, FT-IR spectral study was conducted. Concrete samples were smashed and the steel reinforcements were taken after 480 days of investigation and the deposited oxide film was carefully scratched from the steel rebar surface with a stainless steel blade and performed FT-IR spectroscopic analysis using $\mathrm{KBr}$ pellet method. The spectrum was recorded by Fourier Transform Infrared Spectrophotometer (Model- IR Affinity-1) in the range $4000-400 \mathrm{~cm}^{-1}$. In order to analyse the modifications occurred on the steel rebar surface after 480 days of investigation, microscopic studies were conducted by a high-resolution stereo Microscope (Leica Stereo Microscope-No. S8ACO).

\section{SN Applied Sciences}




\subsection{Compressive strength measurements}

The effect of the admixture (PST) on the strength of concrete after 28 days was determined by compressive strength analysis of concrete by means of a standard vibration machine(Integrated Instruments, India). M-20 concrete blocks of size $150 \times 150 \times 150 \mathrm{~mm}$ were casted with and without PST and the compressive strength was determined.

\section{Results and discussion}

\subsection{Electrochemical investigations}

\subsubsection{Potentiodynamic polarization studies}

The inhibition efficiency of penta sodium triphosphate (PST) on concrete steel reinforcement corrosion was assessed by polarization experiments. Three sets of analysis were done during 480 days, at an interval of 160 days. The data obtained by the analysis of Tafel curves are given in Table 1. A sharp decrease in corrosion current density $\left(\mathrm{i}_{\text {corr }}\right)$ was observed for the embedded rebar in the concrete mixed with PST. Generally, the corrosion inhibition efficacy of inhibitors depends upon various factors including their molecular size, way of interaction and complex formation with metals. On the 160th day of investigation, penta sodium tri-phosphate showed only $61 \%$ of inhibition efficiency. But along with time, the efficiency increased and displayed $68 \%$ and $78 \%$ respectively for 320th and 480th days of investigation. These results support the proposal that PST molecules in the concrete specimen migrates slowly towards the steel surface, adsorbs and make a protective film barrier on the steel, thus obstructing the attack of $\mathrm{Cl}^{-}$on the surface of reinforced steel. The adsorption of PST on the steel rebar surface can be explained by the formation of coordinate bonds using $\pi$-electrons on phosphate group. Chemical structure of PST explains its capability to bind with the metal ions as a bidentate as well as a tridentate chelating agent. This facilitates the complex formation with dissolved Fe ions and effectively reduces the rate of corrosion.
In other words, PST can resist the conversion of $\mathrm{Fe}^{2+}$ ions into hydrated $\mathrm{Fe}(\mathrm{OH})_{3}$ (rust) efficiently. The inhibition mechanism and the structure of PST are shown in Fig. 4.

The results presented in Table 1 and Fig. 4 implies that mixing of PST with concrete results to a change of corrosion potential $\left(\mathrm{E}_{\text {corr }}\right)$ towards the negative direction. If the shift of $E_{\text {corr }}$ is $>85$ and concerning $E_{\text {corr }}$ of the uninhibited specimen along with the significant change of cathodic, or anodic slopes, the inhibitor can be viewed as anodic or cathodic. While the change of $E_{\text {corr }}$ values is $<85 \mathrm{mV}$, the inhibitor behaves as mixed type inhibitor. In the present investigation, PST affects the anodic and cathodic slopes uniformly and therefore it can be regarded as mixed-type inhibitor. The anodic and cathodic tafel slopes $\left(b_{a}\right.$ and $\left.b_{c}\right)$ varied with the exposure time significantly (Fig. 5).

\subsubsection{Electrochemical impedance spectroscopic studies (EIS)}

Electrochemical impedance spectroscopy has been considered as an effective method for the study where polarization measurements failed to provide the correct values of current densities. Since impedance measurements provide the kinetic and mechanistic details, this technique is considered as an important method for the study of corrosion. The inhibition efficiency of PST on concrete steel reinforcement was measured by EIS and the resultant Nyquist plots are given in Fig. 6.

The aim of EIS measurement is to confirm that the electrochemical system fits a specific equivalent-circuit model. This is experimentally done by observing the electrochemical system response to an ac excitation signal over a wide range of frequencies, and the system impedance can be calculated. Impedance, $Z$, is a measurement of the tendency of the circuit to resist the flow of an alternating electrical current. EIS analyses were done with the help of a model equivalent circuit. Out of various model circuits considered, the most suitable one which mimics the electrochemical system under study consists of a parallel combination of two components. First component comprised of a series combination of a double layer capacitance $C_{d l}$ and resistance $R_{S}$, and the second component is made up of Warburg resistance (W) and charge transfer
Table 1 Potentiodynamic polarization parameters of steel reinforcement on 160th, 320 th and 480th days of investigation

\begin{tabular}{lllllll}
\hline Time (days) & Sample & $i_{\text {corr }}\left(\mu \mathrm{A} / \mathrm{cm}^{2}\right)$ & $b_{\mathrm{a}}\left(\mathrm{mV} / \mathrm{dec}^{\prime}\right)$ & $-b_{\mathrm{c}}\left(\mathrm{mV} / \mathrm{dec}^{\prime}\right)$ & $-E_{\text {corr }}(\mathrm{mV})$ & $\eta_{\text {pol }}(\%)$ \\
\hline \multirow{2}{*}{360} & SAMPLE 1 & 161 & 496 & 159 & 651 & \\
\multirow{3}{*}{320} & SAMPLE 2 & 63 & 535 & 176 & 628 & 61 \\
\multirow{4}{*}{480} & SAMPLE 1 & 139 & 489 & 156 & 662 & \\
& SAMPLE 2 & 45 & 411 & 207 & 615 & 68 \\
& SAMPLE 1 & 107 & 373 & 215 & 551 & \\
& SAMPLE 2 & 24 & 375 & 218 & 494 & 78 \\
\hline
\end{tabular}


Fig. 4 a Structure of PST, $\mathbf{b}$ Fe-PST chelated structure, $\mathbf{c}$ protective film formation of PST on steel reinforcement, d formation of $\left[\mathrm{Fe}^{2+}-\mathrm{PST}\right]$ complex $\mathbf{a}$<smiles>[NH3+]OP(=O)(O[Na])OP(=O)(O[Na])OP(=O)(O[Na])O[Na]</smiles>

b<smiles>O=P(O)(OP)OP(=O)(O)OP(=O)(O)Op1op1F</smiles>

$\mathrm{Fe}$

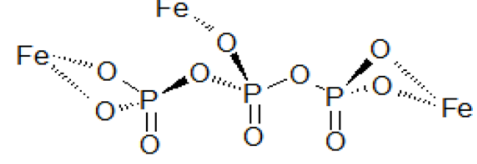

c

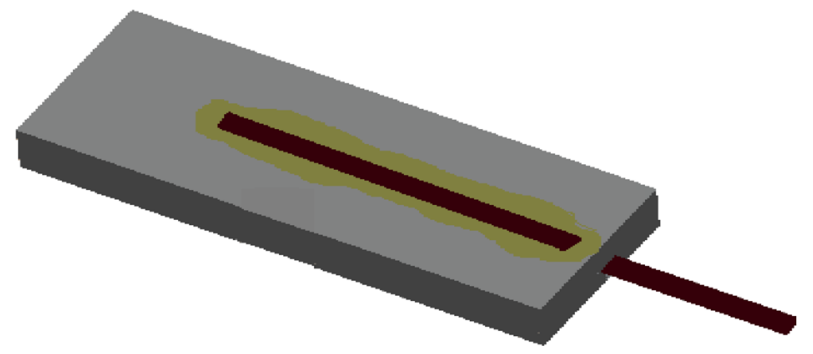

d
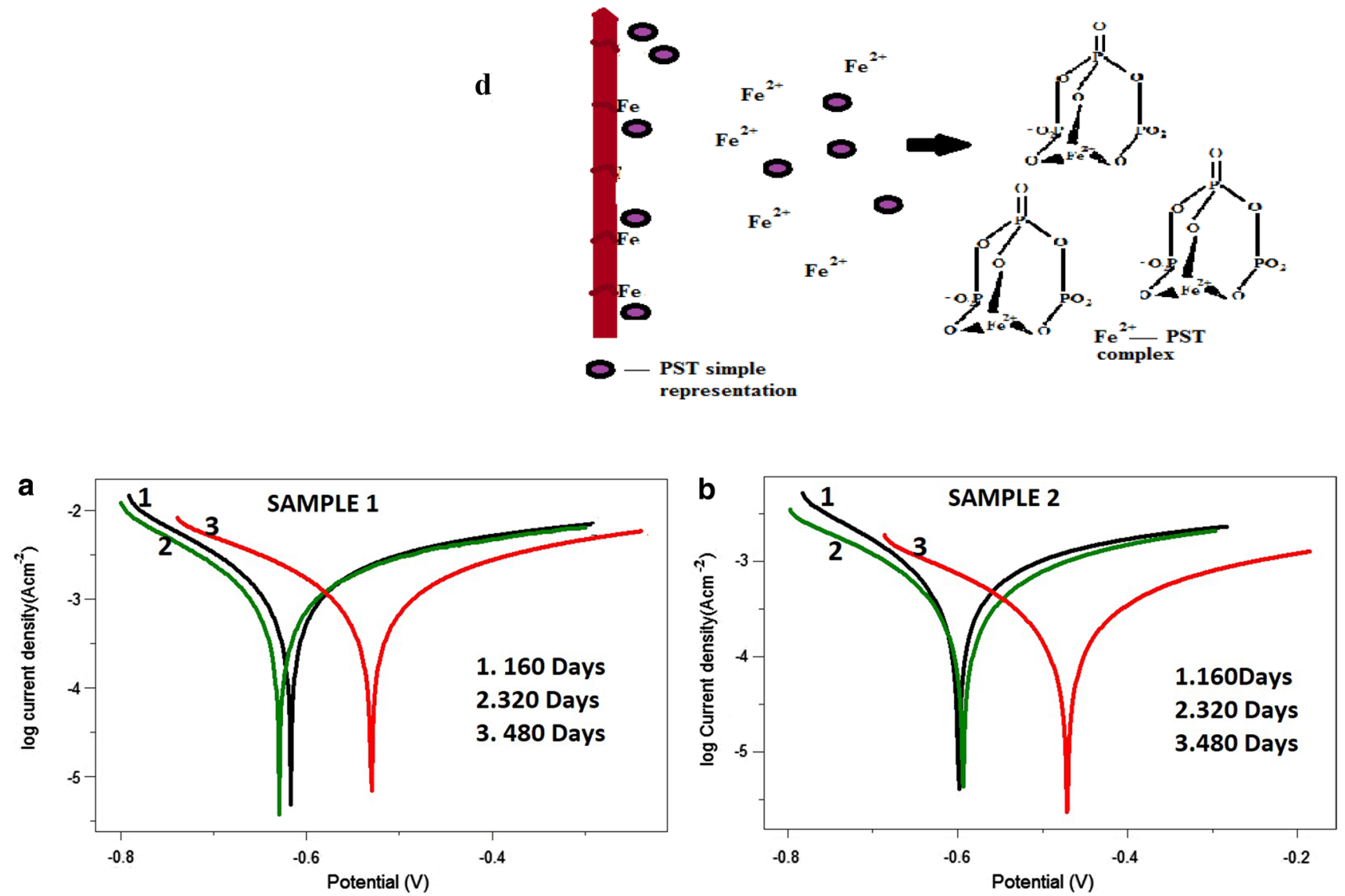

Fig. 5 Tafel curves of steel reinforcement in a SAMPLE 1, b SAMPLE 2 on 160th, 320th and 480th days of investigation

resistance $\mathrm{R}_{\mathrm{ct}}$, connected in series. Both components are connected in parallel to constitute the circuit (Fig. 7). The EIS parameters are depicted in Table 2. On 160th day of investigation, PST displayed $63 \%$ corrosion inhibition efficiency on steel reinforcement in contaminated concrete. Nevertheless, the efficiency was notably increased to 76 and $79 \%$ respectively on 320 th and 480 th days of investigation.

Capacitance measurements illustrate the mechanism of the film formation at the electrode. During the electrochemical measurements, it was observed that the $C_{d l}$ values decreases and it can be explained by the decrease 

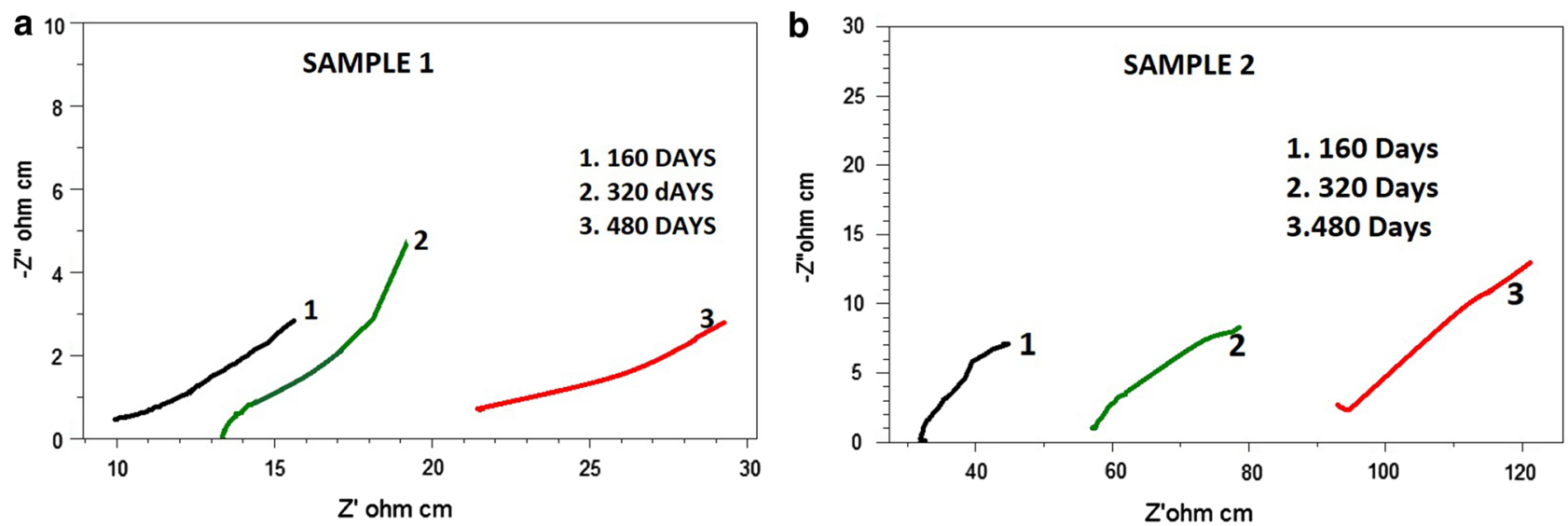

Fig. 6 Nyquist plots of steel reinforcement in a SAMPLE 1 and $\mathbf{b}$ SAMPLE 2 on 160th, 320th and 480th days of investigation

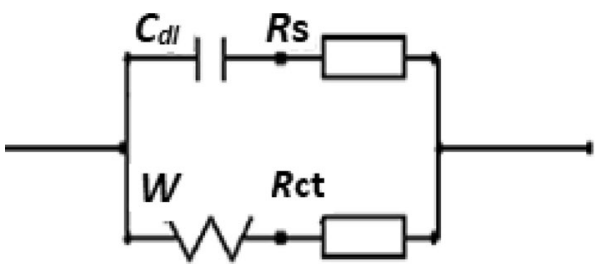

Fig. 7 Equivalent circuit used for EIS analysis

of its electrical capacity. The adsorption of the inhibitor molecules on the electrode surface displaces the water molecules and other ions adsorbed initially on the surface, and thereby reduce the electrical capacity. Addition of PST into the concrete mixture resulted in the increase of $R_{c t}$ value and the decrease of $C_{d l}$ value which is evident from impedance data. The increase of $R_{c t}$ value indicated that PST has a strong tendency to prevent the rate controlling charge transfer process of corrosion, and the decrease in the capacitance revealed that PST makes an efficient protective film on the electrode surface.

\subsubsection{Half-cell potential measurements}

Half-cell potential monitoring of steel reinforcement in the contaminated concrete specimen was regularly carried out to obtain a quick corrosion response. Potential data of steel rebar against SCE for a period of 480 days ( 1 reading per month) with and without PST are given in Table 3 and also represented in the form a line diagram (Fig. 8). Figure 7 shows the variation of steel rebar potential with time. It is quite evident that, the potential values of steel in sample 2 drifted towards noble side as the time progress. The steel rebar in sample 1 was more vulnerable to corrosion as the exhibited potential values. In other

Table 3 Half-cell potential measurements on steel reinforcement in concrete in the presence and absence of PST for 480 days

\begin{tabular}{|c|c|c|c|c|c|}
\hline \multirow[t]{2}{*}{$\begin{array}{l}\text { Time } \\
\text { (days) }\end{array}$} & \multicolumn{2}{|c|}{$\begin{array}{l}\text { Half-cell potential } \\
(\mathrm{mV})\end{array}$} & \multirow[t]{2}{*}{$\begin{array}{l}\text { Time } \\
\text { (days) }\end{array}$} & \multicolumn{2}{|c|}{$\begin{array}{l}\text { Half-cell potential } \\
(\mathrm{mV})\end{array}$} \\
\hline & $\begin{array}{l}\text { SAMPLE } \\
1\end{array}$ & $\begin{array}{l}\text { SAMPLE } \\
2\end{array}$ & & $\begin{array}{l}\text { SAMPLE } \\
1\end{array}$ & SAMPLE 2 \\
\hline 30 & -607 & -525 & 270 & -611 & -405 \\
\hline 60 & -588 & -531 & 300 & -592 & -458 \\
\hline 90 & -580 & -509 & 330 & -625 & -410 \\
\hline 120 & -555 & -531 & 360 & -628 & -358 \\
\hline 150 & -560 & -493 & 390 & -589 & -333 \\
\hline 180 & -554 & -457 & 420 & -602 & -363 \\
\hline 210 & -567 & -489 & 450 & -597 & -390 \\
\hline 240 & -578 & -422 & 480 & -600 & -385 \\
\hline
\end{tabular}

Table 2 EIS parameters of steel reinforcement on 160 th, 320th and 480th days of investigation

\begin{tabular}{llcllll}
\hline Time (days) & Sample & $W\left(\Omega \mathrm{cm}^{2}\right)$ & $R_{\mathrm{s}}\left(\Omega \mathrm{cm}^{2}\right)$ & $C_{\mathrm{dl}}\left(\mu \mathrm{F} \mathrm{cm}{ }^{-2}\right)$ & $R_{\mathrm{ct}}\left(\Omega \mathrm{cm}^{2}\right)$ & $\eta_{\mathrm{EIS}}(\%)$ \\
\hline 160 & SAMPLE 1 & 2.74 & 78.5 & 886 & 11.9 & \\
& SAMPLE 2 & 8.69 & 162 & 512 & 32.4 & 63 \\
320 & SAMPLE 1 & 3.78 & 75.6 & 839 & 14.7 & \\
\multirow{3}{*}{480} & SAMPLE 2 & 12.8 & 128 & 506 & 61 & 76 \\
& SAMPLE 1 & 3.23 & 223 & 801 & 24.3 & \\
& SAMPLE 2 & 9.27 & 459 & 242 & 117 & 79.2 \\
\hline
\end{tabular}




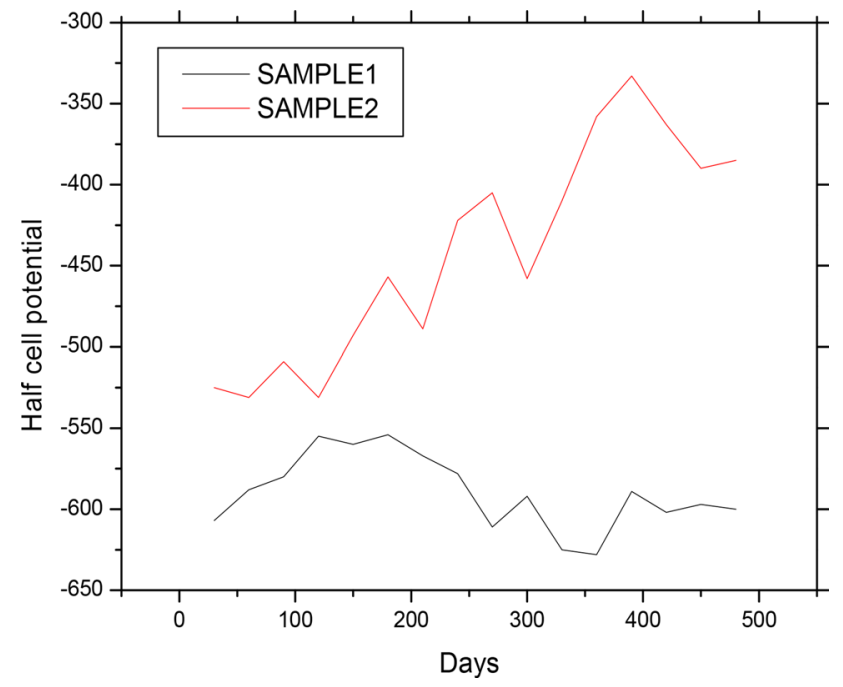

Fig. 8 Half-cell potential of steel reinforcement in SAMPLE 1 and SAMPLE 2 during 480 days

words the steel rebar in sample 1 showed more anodic behaviour than sample 2 rebar. The half-cell potentials of contaminated concrete (Sample 1) were more negative (about 500-600 mV), indicating high corrosion probability. Whereas, half-cell potential values of steel reinforcement in concrete modified with PST, were increased to $-385 \mathrm{mV}$. The significant decline in the potential is due to the inhibition capability of penta sodium triphosphate on the steel surface. These results are in good agreement with the data obtained from polarization and impedance studies. Thus, the efficacy of PST molecules in mitigating the corrosion of steel reinforcement for a long period in contaminated concrete is once again established using potential studies.

\subsection{Gravimetric studies}

Gravimetric studies of steel reinforcement in contaminated concrete with and without inhibitor were carried out to establish the weight loss of steel reinforcement and corrosion inhibitory potency of PST. The weight loss of reinforced steel embedded in concrete mixed with PST was found to reduce considerably compared to the blank specimen. Steel rebars of sample 1 and sample 2 exhibited $24.6 \%$ and $3.9 \%$ weight loss respectively after 480 days of investigation, which clearly indicated that PST displayed $84 \%$ of corrosion inhibition efficacy on reinforced steel in contaminated concrete. The low weight loss of the rebar in modified concrete is due to the prevention of $\mathrm{Cl}^{-}$attack by the protective film formed by the PST on the steel surface. Elevated weight loss of steel rebar in the uninhibited concrete indicated that the specimen is highly susceptible to $\mathrm{Cl}^{-}$ions attack and corrosion.

\subsection{FTIR analysis}

The mechanism of interaction of penta sodium triphosphate molecules on steel rebar surface embedded in the concrete was evaluated using FTIR spectroscopy. The interpretation of the spectrum of the corrosion product on the steel surface was arduous due to the presence of various compounds in corrosion product. However, categorical changes were observed in the stretching/bending frequencies of corrosion products of rebar collected from sample 1 and sample 2 . At $3375 \mathrm{~cm}^{-1}$ a broad peak observed in the IR spectrum of products obtained from sample 1 can be assigned to the stretching vibration of $-\mathrm{OH}$ of both $\mathrm{Fe}(\mathrm{OH})_{2}$ and hydrated $\mathrm{Fe}(\mathrm{OH})_{3}$ deposited on steel rebar surface. Marked shifting of this peak to $3016 \mathrm{~cm}^{-1}$ was noted for the corrosion product collected from sample 2 which indicates the intervention of PST molecules on the corrosion process. The FTIR spectrum of pure PST displayed asymmetric stretching peaks of phosphate moiety at $1065 \mathrm{~cm}^{-1}$ and $1415 \mathrm{~cm}^{-1}$ and bending peaks at $479 \mathrm{~cm}^{-1}$ and $606 \mathrm{~cm}^{-1}$. The stretching frequencies were shifted to $922 \mathrm{~cm}^{-1}$ and $1382 \mathrm{~cm}^{-1}$ and bending peaks were shifted to $447 \mathrm{~cm}^{-1}$ and $557 \mathrm{~cm}^{-1}$ in IR spectra of corrosion products from sample 2. Some of the intense peaks observed in IR spectrum of PST were absent in the spectrum of corrosion products of sample 2 . These significant changes in the IR spectra are a clear indication of the interaction of PST with the steel surface. IR spectrum of PST and corrosion products scratched from the steel rebar in sample 1 and 2 are represented in Fig. 9.

\subsection{Microscopic surface analysis}

Examination of the optical micrographs indicated that the surface morphology of steel rebars embedded in the concrete specimens were uneven when compared to the morphology of bare rebar, due to deposition of hydrated $\mathrm{Fe}(\mathrm{OH})_{3}$ (rust) on the steel surface. The texture of steel rebar present in sample 2 significantly differed from that of sample 1. The surface of this rebar appeared to be less corroded as its surface hada thin oxide film (Fig. 10), compared to the rebar in sample 1. This suggests that PST possesses significant anti corrosive ability to prevent corrosion of steel rebars in concrete, contaminated with $\mathrm{NaCl}$.

\subsection{Compressive strength measurements}

Compressive strength of concrete specimens was measured to evaluate the effect of PST on the strength of concrete [62]. As described in experimental procedure, $M-20$ concrete blocks were casted with and without PST and the compressive strengths were determined after 28 days. Both the test specimens displayed almost equal values of 

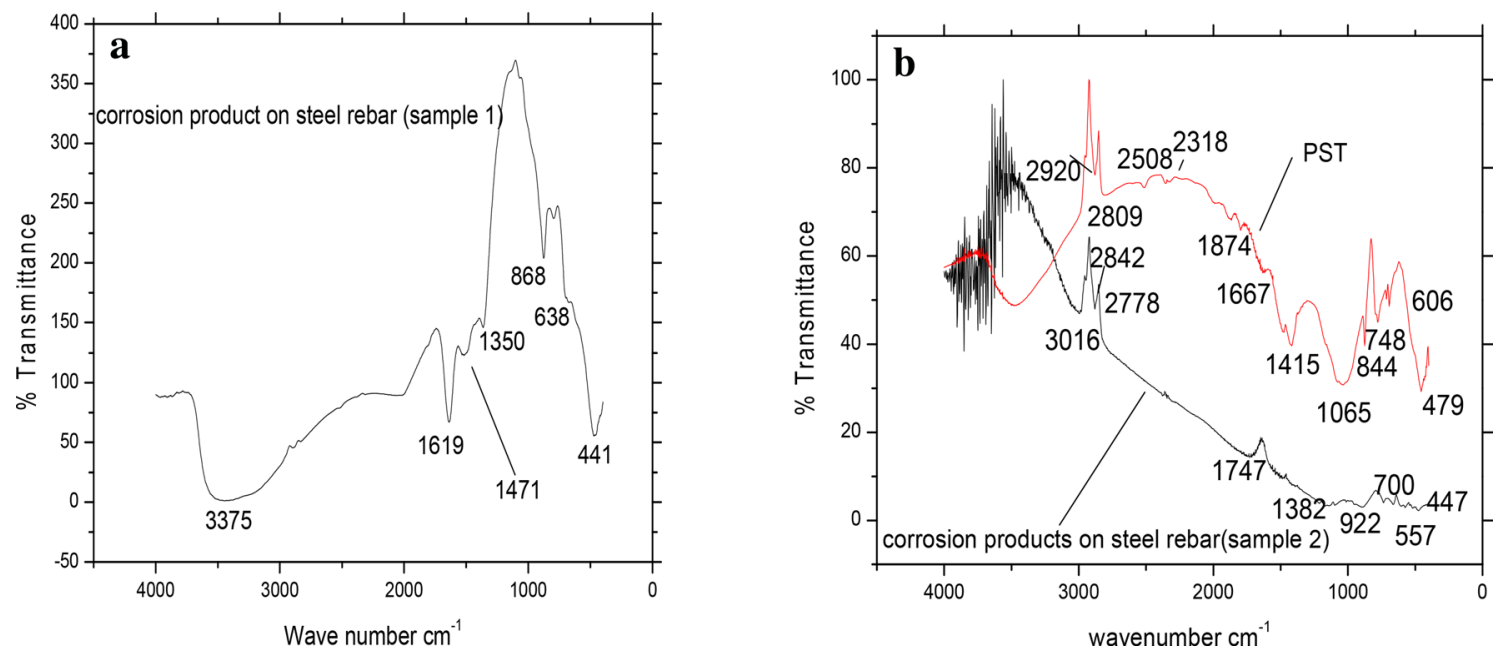

Fig. 9 IR spectra of corrosion products deposited on the steel reinforcement in a SAMPLE 1 and $\mathbf{b}$ SAMPLE 2 and spectrum of PST

Fig. 10 Optical micrographs of steel reinforcement $\mathbf{a}$ bare $\mathbf{b}$ in SAMPLE 1 and $\mathbf{c}$ in SAMPLE 2

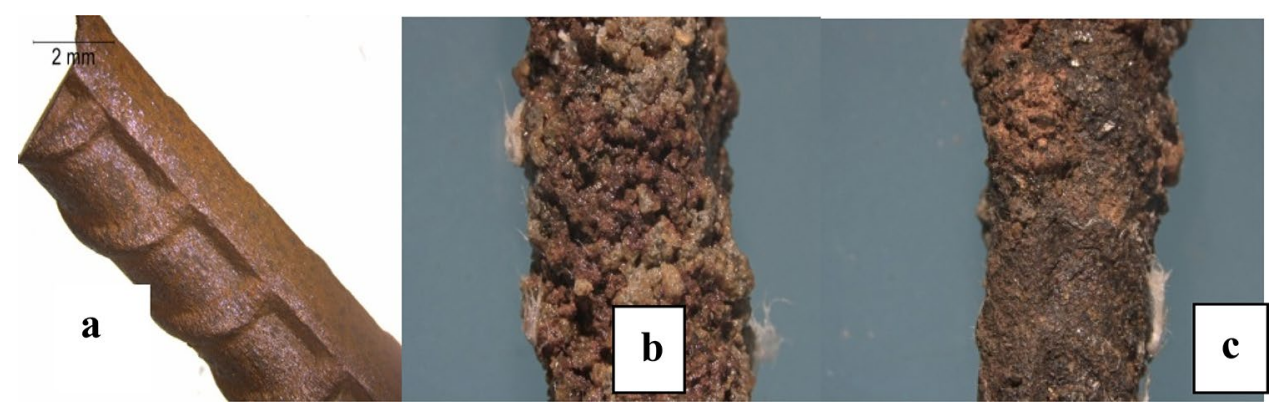

compressive strength. M-20 concrete specimen without PST and with PST showed compressive strengths of 21.33 and $21.30 \mathrm{~N} / \mathrm{m}^{2}$ respectively, suggesting that PST molecules has no adverse effect on the strength of concrete.

\section{Conclusion}

In this work, we investigated the corrosion inhibition efficacy of penta sodium triphosphate on steel reinforcement in concrete contaminated with $3.5 \% \mathrm{NaCl}$. The potentiodynamic polarization and EIS studies acquiesced that when PST inhibitor effectively drop the corrosion rate of steel reinforcement, when it used as an admixture in concrete structures. The increase of inhibition efficiency up to $78-79 \%$ during 480 days of investigation was attributed to the development of effective protective film of PST over the steel surface. Potentiodynamic polarisation results revealed that PST affects the anodic and cathodic sites of corrosion uniformly and therefore it can be regarded as mixed-type inhibitor. Half-cell potential measurement confirmed that steel embedded in concrete modified with PST has effective corrosion resisting capability. Gravimetric analysis demonstrated that the deterioration of steel reinforcement in concrete mixed with PST was effectively reduced and this study proved the capacity of PST to form a protective barrier on steel surface. Spectroscopic and microscopic analysis of the steel reinforcement specimens expounded the corrosion inhibition mechanism of PST and surface modification of reinforced steel. Compressive strength measurements proved that addition of PST has no adverse effect on the strength of concrete.

\section{Compliance with ethical standards}

Conflict of interest On behalf of all authors, the corresponding author states that there is no conflict of interest.

\section{References}

1. Almusallam AA (2001) Effect of degree of corrosion on the properties of reinforcing steel bars. Constr Build Mater 15:361-368

2. Dehwah HAF, Maslehuddin M, Austin SA (2002) Longterm effect of sulfate ions and associated cation type on 
chloride-induced reinforcement corrosion in Portland cement concretes. Cem Concr Compos 24:17-25

3. Aguiar JB, Júnior C (2013) Carbonation of surface protected concrete. Constr Build Mater 49:478-483

4. Sideris KK, Anagnostopoulos NS (2013) Durability of normal strength self-compacting concretes and their impact on service life of reinforced concrete structures. Constr Build Mater 41:491-497

5. Sisomphon K, Franke L (2007) Carbonation rates of concretes containing high volume of pozzolanic materials. Cem Concr Res 37:1647-1653

6. Rodriguez J, Ortega LM, Casal J (1997) Load carrying capacity of concrete structures with corroded reinforcement. Constr Build Mater 11:239-248

7. Uthaman S, Philip J (2019) Enhanced seawater corrosion resistance of reinforcement in nanophase modified fly ash concrete. Constr Build Mater 221:232-243

8. Xiao QH, Liu XL (2019) Damage to recycled concrete with different aggregate substitution rates from the coupled action of freeze-thaw cycles and sulfate attack. Constr Build Mater 221:74-83

9. Keleştemur O, Yıldız S (2009) Effect of various dual-phase heat treatments on the corrosion behavior of reinforcing steel used in the reinforced concrete structures. Constr Build Mater 23:78-84

10. Duffó GS, Farina SB (2009) Development of an embeddable sensor to monitor the corrosion process of new and existing reinforced concrete structures. Constr Build Mater 23:2746-2751

11. Muntean A, Böhm M, Kropp J (2011) Moving carbonation fronts in concrete: a moving-sharp-interface approach. Chem Eng Sci 66:538-547

12. Apostolopoulos CA, Papadakis VG (2008) Consequences of steel corrosion on the ductility properties of reinforcement bar. Constr Build Mater 22:2316-2324

13. Enevoldsen JN, Hansson CM, Hope BB (1994) The influence of internal relative humidity on the rate of corrosion of steel embedded in concrete and mortar. Cem Concr Res 24:1373-1382

14. Vidal T, Castel A, François R (2004) Analyzing crack width to predict corrosion in reinforced concrete. Cem Concr Res 34:165-174

15. Altoubat S, Maalej ShaikhFUA (2016) Ductile fibre reinforced cementitious composites (DFRCC) for improved corrosion durability of reinforced concrete columns. Int J Concr Struct Mater 10:383-391

16. Stewart MG, Rosowsky DV (1998) Time-dependent reliability of deteriorating reinforced concrete bridge decks. Struct Saf 20:91-109

17. Dakhil FH, Bader MA, Khan MM (1992) Performance of corrosionresisting steels in chloride-bearing concrete. Mater J 89:439-448

18. Pradhan B, Bhattacharjee B (2009) Performance evaluation of rebar in chloride contaminated concrete by corrosion rate. Constr Build Mater 23:2346-2356

19. Vu KAT, Stewart MG (2000) Structural reliability of concrete bridges including improved chloride-induced corrosion models. Struct Saf 22:313-333

20. Abosrra $L$, Ashour AF, Youseffi $M(2011)$ Corrosion of steel reinforcement in concrete of different compressive strengths. Constr Build Mater 25:3915-3925

21. Duffó GS, Farina SB, Giordano CM (2009) Characterization of solid embeddable reference electrodes for corrosion monitoring in reinforced concrete structures. Electrochim Acta 54:1010-1020

22. Chen D, Mahadevan S (2008) Chloride-induced reinforcement corrosion and concrete cracking simulation. Cem Concr Compos $30: 227-238$
23. Zehua D, Shi W, Peng Guo X (2011) Initiation and repassivation of pitting corrosion of carbon steel in carbonated concrete pore solution. Corros Sci 53:1322-1330

24. Chen A (2013) Study of pitting corrosion on mild steel during wet-dry cycles by electrochemical noise analysis based on chaos theory. Corros Sci 66:183-195

25. González JA, Andrade C, Alonso C, Feliu S (1995) Comparison of rates of general corrosion and maximum pitting penetration on concrete embedded steel reinforcement. Cem Concr Res 25:257-264

26. Stewart MG (2004) Spatial variability of pitting corrosion and its influence on structural fragility and reliability of RC beams in flexure. Struct Saf 26:453-470

27. Stewart MG, Al-Harthy A (2008) Pitting corrosion and structural reliability of corroding $\mathrm{RC}$ structures: experimental data and probabilistic analysis. Reliab Eng Syst Saf 93:373-382

28. Diamanti MV, Brenna A, Bolzoni F, Berra M (2013) Effect of polymer modified cementitious coatings on water and chloride permeability in concrete. Constr Build Mater 49:720-728

29. Bautista A, Alvarez SM, Paredes EC (2013) Corrugated stainless steels embedded in carbonated mortars with and without chlorides: 9-year corrosion results. Constr Build Mater 95:186-196

30. Stewart MG (2009) Mechanical behaviour of pitting corrosion of flexural and shear reinforcement and its effect on structural reliability of corroding RC beams. Struct Saf 31:19-30

31. Söylev TA, Richardson MG (2008) Corrosion inhibitors for steel in concrete: state-of-the-art report. Constr Build Mater 22:609-622

32. Gaidis JM (2004) Chemistry of corrosion inhibitors. Cem Concr Compos 26:181-189

33. Gaidis J, Rosenberg A (1987) The inhibition of chloride-induced corrosion in reinforced concrete by calcium nitrite. Cem Concr Aggreg 9:30-33

34. Malik AU, Andijani I, Al-Moaili F, Ozair G (2004) Studies on the performance of migratory corrosion inhibitors in protection of rebar concrete in Gulf seawater environment. Cem Concr Compos 26:235-242

35. Saraswathy V, Song HW (2007) Improving the durability of concrete by using inhibitors. Build Environ 42:464-472

36. Saricimen H, Mohammad M, Quddus A (2002) Effectiveness of concrete inhibitors in retarding rebar corrosion. Cem Concr Compos 24:89-100

37. Sideris KK, Sava AE (2005) Durability of mixtures containing calcium nitrite based corrosion inhibitor. Cem Concr Compos 27:277-287

38. Montes P, Bremner TW, Lister DH (2004) Influence of calcium nitrite inhibitor and crack width on corrosion of steel in high performance concrete subjected to a simulated marine environment. Cem Concr Compos 26:243-253

39. Wombacher F, Maeder U, Marazzani B (2004) Aminoalcohol based mixed corrosion inhibitors. Cem Concr Compos 26:209-216

40. Asaad MA (2018) Enhanced corrosion resistance of reinforced concrete: role of emerging eco-friendly Elaeis guineensis/silver nanoparticles inhibitor. Constr Build Mater 188:555-568

41. Zhou C, Zhou C, Zhang J (2019) Investigation of corrosion resistance of poly(ophenylenediamine)- $\mathrm{ZnO}$ composites on stainless steel. Int J Electrochem Sci 14:8173-8184

42. Yohai L, Schreiner W, Vázquez M (2016) Phosphate ions as effective inhibitors for carbon steel in carbonated solutions contaminated with chloride ions. Electrochim Acta 202:231-242

43. Shi JJ, Sun W (2014) Effects of phosphate on the chlorideinduced corrosion behavior of reinforcing steel in mortars. Cem Concr Compos 45:166-175

44. Ashassi-Sorkhabi H, Shaabani B, Seifzadeh D (2005) Corrosion inhibition of mild steel by some Schiff base compounds in hydrochloric acid. Appl Surf Sci 239:154-164 
45. Kuruvilla M, John S, Joseph A (2016) Electroanalytical studies on the interaction of L-serine-based schiff base, HHDMP, with copper in sulphuric acid. J Bio Tribo Corr 2:19

46. Kumari PP, Rao SA, Shetty P (2014) Corrosion inhibition of mild steel in $2 \mathrm{M} \mathrm{HCl}$ by a Schiff base derivative. Proc Mater Sci 5:499-507

47. Mance A, Cerović D, Mihajlović A (1984) The effect of small additions of indium and thallium on the corrosion behaviour of aluminium in sea water. J Appl Electrochem 14:459-466

48. Beck TR (1984) Salt film formation during corrosion of aluminum. Electrochim Acta 29:485-491

49. Gawin D (2002) Hygro-thermo-chemo-mechanical modelling of concrete at early ages and beyond. Part I: hydration and hygro-thermal phenomena. Comput Methods Appl Mech Eng 192:1731-1771

50. Shi J, Sun W, Jiang J, Zhang Y (2016) Influence of chloride concentration and pre-passivation on the pitting corrosion resistance of low-alloy reinforcing steel in simulated concrete pore solution. Constr Build Mater 111:805-813

51. Yang C, Li L, Li J (2020) Service life of reinforced concrete seawalls suffering from chloride attack: theoretical modelling and analysis. Constr Build Mater 263:10

52. Kiesse TS, Bonnet S, Amiri O, Ventura A (2020) Analysis of corrosion risk due to chloride diffusion for concrete structures in marine environment. Mar Struct 73:102804

53. Du F, Jin Z, She W, Xiong C (2020) Chloride ions migration and induced reinforcement corrosion in concrete with cracks: a comparative study of current acceleration and natural marine exposure. Constr Build Mater 263:120099

54. Chan CWWJ, Wu ML (2000) Durability of concrete with high cement replacement. Cem Concr Res 30:865-879

55. Al-Akhras NM, Al-Akhras KM, Attom MF (2009) Performance of olive waste ash concrete exposed to elevated temperatures. Fire Saf J 44:370-375
56. Raphael VP, Joby Thomas K, Shaju KS (2017) Influence of 3-acetylpyridine phenylhydrazone on the corrosion of carbon steel in hydrochloric acid. Int J Chem Technol 24:61-66

57. Shaju KS, Joby Thomas K, Raphael VP (2015) Electrochemical and AFM studies on adsorption behavior of a polynuclear schiff base at carbon steel in $\mathrm{HCl}$ medium. Curr Chem Lett 5:67-76

58. Bastidas DM, Criado M, Fajardo S (2015) Corrosion inhibition mechanism of phosphates for early-age reinforced mortar in the presence of chlorides. Cem Concr Compos 61:1-6

59. Bastidas DM (2013) Comparative study of three sodium phosphates as corrosion inhibitors for steel reinforcements. Cem Concr Compos 43:31-38

60. Yohai L, Valcarce MB, Vázquez M (2016) Testing phosphate ions as corrosion inhibitors for construction steel in mortars. Electrochim Acta 202:316-324

61. Zhu Y, Free ML, Yi G (2015) Electrochemical measurement, modeling, and prediction of corrosion inhibition efficiency of ternary mixtures of homologous surfactants in salt solution. Corros Sci 98:417-429

62. Paulson BM, Joby Thomas K, Raphael VP (2018) Efficacies of sodium nitrite and sodium citrate-zinc acetate mixture to inhibit steel rebar corrosion in simulated concrete interstitial solution contaminated with $\mathrm{NaCl}$. Int J Ind Chem 9:105-114

Publisher's Note Springer Nature remains neutral with regard to jurisdictional claims in published maps and institutional affiliations. 